\section{Chronic noncommunicable diseases multimorbidity and its association with physical activity and television time in a representative Brazilian population}

\author{
Multimorbidade de doenças crônicas não \\ transmissíveise associação com atividade \\ física e tempo de televisão em uma \\ população brasileira representativa
}

\section{Multimorbilidad de enfermedades crónicas no transmisibles y su asociación con la actividad física y tiempo frente a la televisión en una población representativa brasileña}

\begin{abstract}
Lifestyle behaviors need to be more explored within the context of chronic noncommunicable disease (NCD) multimorbidity. This study aimed to investigate the association of multimorbidity with physical activity and sedentary behavior in a representative Brazilian population $(n=52,929)$. A cross-sectional survey (VIGITEL in the Portuguese acronym) was conducted in 2013 in the 27 Brazilian federal units. Multimorbidity is defined as the presence of two or more NCDs, that is, the outcome variable; and physical activity (commuting, domestic chores, leisure, and work domains) and sedentary behavior (television time $<2$ hours/day and $\geq 2$ hours/day) were the exposure variables. Poisson and multinomial logistic regressions (odds ratio OR) stratified by age and their respective 95\% confidence intervals were used, adopting a significance level of 5\%. Among 37,947 adults, the presence of three chronic diseases was less frequent in subjects active in the work domain $(O R=$ $0.60)$ and more frequent among those with longer daily television time $(O R=$ 1.25). The presence of four diseases was less frequent in subjects active in the commuting $(\mathrm{OR}=0.52)$ and work $(\mathrm{OR}=0.42)$ domains. Among 14,982 older adults, the presence of two, three, and four chronic diseases was consistently more frequent in those with longer daily television time $(O R=1.33 ; 1.55$ and 1.93, respectively). Finally, interactions between total physical activity level and daily television time were statistically significant in the multimorbidity in both age groups. Physical activity and sedentary behavior are associated with multimorbidity and should be considered independent factors for health promotion and for the treatment of patients with multimorbidity.
\end{abstract}

Marina Christofoletti

Giovani Firpo Del Duca 1

Daniel Umpierre 2,3

Deborah Carvalho Malta 4

doi: 10.1590/0102-311X00016319

\author{
Correspondence \\ M. Cristofoletti \\ Universidade Federal de Santa Catarina. \\ Campus Reitor João David Ferreira Lima s/n, Florianópolis, SC \\ 88040-900, Brasil. \\ marinachriss@outlook.com \\ 1 Universidade Federal de Santa Catarina, Florianópolis, Brasil. \\ 2 Universidade Federal de Pelotas, Pelotas, Brasil. \\ 3 Hospital das Clínicas de Porto Alegre, Universidade Federal do \\ Rio Grande do Sul, Porto Alegre, Brasil. \\ 4 Universidade Federal de Minas Gerais, Belo Horizonte, Brasil.
}




\section{Introduction}

Multimorbidity is the presence of two or more diagnosed diseases ${ }^{1}$. Multimorbidity is common among older adults 2, but expressive rates of this condition are seen in adults. Chronic noncommunicable diseases (NCDs) individually reduce life expectancy ${ }^{3}$ and are currently the leading death causes worldwide 4 . The coexistence of NCDs aggravates the problems and can result in loss of quality of life and functional capacity, with a consequent increase in the use of health services, in the public spending and in the risk of death 2,5 .

A strong association of NCD multimorbidity with behavior factors has been suggested 6 . Among these factors, physical activity and sedentary behavior are important determinants for the development of NCDs and should not be confused since it has been established that they are independent behaviors characterized by distinct metabolic responses 7 . In this respect, physical activity is considered an important health-protecting factor because it exerts a preventive effect even when performed at intensities below the current health-related recommendations (moderate to vigorous activities) 8 . This effect appears to be greatly enhanced when the levels of activity increase 9 . In contrast, sedentary behavior is a health risk factor 5 , regardless of participation in physical activity, which is related to death from cardiovascular diseases (aggravation of NCD multimorbidity) and associated with the simultaneous diagnosis of different cardiovascular risk indicators 10,11.

Considering that health is a complex of dynamic and interconnected organ systems in which different diseases can occur simultaneously according to the influence of hereditability and behaviors adopted, this study aimed to investigate the association of NCD multimorbidity with physical activity and sedentary behavior in a representative Brazilian population.

\section{Methods}

This was a cross-sectional study, which performed a secondary analysis of data from the annual national survey Risk and Protective Factors Surveillance System for Chronic Non-Communicable Diseases Therough Telephone Interview (VIGITEL - Vigilância de Fatores de Risco e Proteção para Doenças Crônicas por Inquérito Telefônico). Between February and December 2013, data were collected in all 27 capitals of the Brazilian federative units from adults older than 18 years, who had a fixed residential telephone line.

The sampling was performed in three steps 12. Each capital had 2,000 interviewees as minimum sample; therefore, the variables could be estimated with a $95 \%$ confidence interval (95\%CI) and a $3 \%$ maximum error. Weighting factors were used to compensate for bias of nonuniversal fixed-line coverage, adjusted to the adult Brazilian population based on the weight of each individual of the sample calculated by the raking method 12 . The data were collected by telephone interview simultaneously using a computer, and all the calls were recovered. The supervisor checked, listed and made a re-interview in $10 \%$ of the interviews for quality control. The instrument applied, based on previous surveys 12 , had been validated in pilot studies 13,14,15 with satisfactory validity and reliability considering five different cities in each macroregion of Brazil 14, and contained questions about sociodemographic, behavioral, nutritional, and health factors. The section used to assess physical activity was created based on instructions and models from the World Health Organization 16 and the centers for disease control and prevention 17, being validated for Brazilians 18.

The outcome variable was NCD multimorbidity, which was categorized in two ways according to the analysis proposed. For multinomial regression, the outcome had four categories: no occurrence (zero or one disease) and occurrence (two, three, or four diseases) of multimorbidity. For interaction analysis, the outcome was defined by the absence of disease and the presence of two or more diseases. To create the NCD variable, the four most prevalent noncommunicable diseases in Brazil were used, which were diabetes, dyslipidemia, arterial hypertension, and obesity. Diabetes, dyslipidemia, and arterial hypertension were considered when the participant answered yes to the following questions: "Has any doctor ever told you that you have diabetes?"; "Has any doctor ever told you that you have dyslipidemia?”; "Has any doctor ever told you that you have high blood pressure?”. Obesity was defined as a body mass index of $30 \mathrm{~kg} / \mathrm{m}^{2}$ or higher, calculated based on self-reported weight and height. For this variable, hot deck imputation of the data was used to include the blank answers $(8.8 \%)$ 
in the analysis. The control variables were sex, age, marital status, ethnicity, demographic region, and education level. The following exposure variables were used: physical activity performed at least once a week in the commuting, domestic chore, leisure-time, and work domains; total physical activity level in the leisure-time and commuting domains categorized into inactive (none), insufficiently active $(10-149 \mathrm{~min} /$ week), and active ( $\geq 150 \mathrm{~min} /$ week), and daily television time categorized into $<2$ hours and $\geq 2$ hours. We considered these activities because they are usually part of routine activities 19 , and this cut-off for daily television time has been suggested in a previous study 20.

The Stata software (https://www.stata.com) was used for data statistical analysis. For descriptive analysis, absolute and relative frequencies were calculated, considering the prevalence estimates and 95\%CI. For adjusted inferential analysis, multinomial logistic and Poisson regressions were performed, in which the data are expressed as odds ratio (OR) and prevalence ratio (PR), respectively. The first regression aimed to associate behavioral indicators with multimorbidity according to the number of existing diseases. Interaction analysis, defined by describing interdependent effects of two or more variables included in the model, considered total physical activity level and daily television time in multimorbidity occurrence. A multiplicative model was adopted, in which the product derived from the crossing of the tested variables was used in the Poisson regression with robust variance, considering the $\mathrm{p}$-value of the Wald test for heterogeneity. Fitting the regressions, the firstlevel variables were sex, age, marital status, ethnicity, demographic region, and education level; the second-level were commuting, domestic shore, leisure-time and work, physical activity, total physical activity, and daily television time. Backward selection was adopted for statistical modeling, with a $\mathrm{p}$ $\leq 0.20$ critical level for the variable to remain in the hierarchical regression model. A $5 \%$ significance level was adopted for all tests. All analyses considered the sample weight obtained by the inverse of the number of telephone lines existing in the interviewed household and the number of adults living in the interviewee's household.

The National Research Ethics Committee of the Ministry of Health approved this study (protocol number 355.590/2013). All participants consented verbally to participate in the study, via telephone call.

\section{Results}

Among the eligible subjects ( $\mathrm{n}=74,005), 52,929$ participated in the study (response rate of $71.5 \%$ ). The adults' mean age was $36.2 \pm 11.2$ years and most of them were women $(52.9 \%)$ and lived without a partner (52\%). Among the older adults, the mean age was $69.4 \pm 13.3$ years. Women (59.5\%) and individuals living with a partner (56.9\%) were predominant. The multimorbidity frequency of two, three, and four NCDs was $9.8 \%, 3.3 \%$, and $0.6 \%$ in the group of adults, respectively, and $28 \%, 12.6 \%$, and $2.7 \%$ among older adults.

Most adults did not perform physical activity in the domestic chore (59.9\%), commuting (61.9\%), work (56.4\%), or leisure-time (53.3\%) domain. These percentages were $66.8 \%, 86.6 \%, 82.8 \%$, and $63.1 \%$, respectively, among older adults. For total physical activity, most adults were physically active (45.5\%) and most older adults were inactive (58.5\%). In addition, adults and older adults watched television two or more hours per day ( $50.9 \%$ and $55.1 \%$, respectively) (Table 1 ).

Tables 2 and 3 show the behavioral indicators associated with the number of NCDs in multimorbidity in adults and older adults, respectively. Among 37,947 adults, when comparing subjects with none and one disease, the occurrence of two chronic diseases was more frequent among those active in the leisure-time domain $(\mathrm{OR}=1.46,95 \% \mathrm{CI}$ : $1.16 ; 1.84)$ and with longer daily television time $(\mathrm{OR}=$ $1.20,95 \% \mathrm{CI}$ : $1.05 ; 1.38)$. An inverse trend between the presence of two diseases $(\mathrm{p}<0.001)$ and total physical activity was observed. The occurrence of three chronic diseases was less frequent in subjects active in the work domain $(\mathrm{OR}=0.60,95 \% \mathrm{CI}: 0.46 ; 0.78)$ and more frequent in those with longer daily television time ( $\mathrm{OR}=1.50,95 \% \mathrm{CI}: 1.20 ; 1.88)$. The occurrence of four diseases was less frequent in subjects active in the work domain $(\mathrm{OR}=0.48,95 \% \mathrm{CI}: 0.27 ; 0.82)$.

Among 14,982 older adults, the occurrence of two diseases was less frequent in those active in the domestic domain $(\mathrm{OR}=0.77,95 \% \mathrm{CI}$ : $0.65 ; 0.92)$ and in those with four diseases in the domestic (OR: $0.56,95 \% \mathrm{CI}$ : $0.34 ; 0.93)$ and work domains $(\mathrm{OR}=0.26,95 \% \mathrm{CI}$ : $0.11 ; 0.62)$. The presence of two and 
Table 1

Behavioral variables stratified by age. Brazil, $2013(n=52,929)$.

\begin{tabular}{|c|c|c|c|c|c|c|c|c|}
\hline \multirow[t]{2}{*}{ Variable } & \multicolumn{4}{|c|}{ Adults $(n=37,947)$} & \multicolumn{4}{|c|}{ Older adults $(n=14,982)$} \\
\hline & $\mathbf{n}$ & $\%$ * & $95 \% \mathrm{Cl} * *$ & Missing (\%) & $\mathbf{n}$ & $\%$ * & $95 \% \mathrm{Cl} * *$ & Missing (\%) \\
\hline Domestic physical activity & & & & 0.3 & & & & 0.4 \\
\hline No & 21,981 & 59.9 & $59.0 ; 60.9$ & & 10,205 & 66.8 & $65.2 ; 68.4$ & \\
\hline Yes & 15,903 & 40.1 & $39.1 ; 41.0$ & & 4,725 & 33.2 & $31.6 ; 34.8$ & \\
\hline Commuting physical activity & & & & 0.7 & & & & 1.0 \\
\hline No & 26,135 & 61.9 & $60.9 ; 62.9$ & & 13,248 & 86.6 & $85.3 ; 87.9$ & \\
\hline Yes & 11,539 & 38.1 & $37.1 ; 39.1$ & & 1,588 & 13.4 & $12.1 ; 14.7$ & \\
\hline Work physical activity & & & & 0.0 & & & & 0.0 \\
\hline No & 22,895 & 56.4 & $55.4 ; 57.4$ & & 12,781 & 82.8 & $81.4 ; 84.2$ & \\
\hline Yes & 15,038 & 43.6 & $42.6 ; 44.6$ & & 2,198 & 17.2 & $15.8 ; 18.6$ & \\
\hline Leisure-time physical activity & & & & 0.0 & & & & 0.0 \\
\hline No & 18,868 & 53.3 & $52.3 ; 54.3$ & & 8,141 & 63.1 & $61.5 ; 64.7$ & \\
\hline Yes & 19,079 & 46.7 & $45.7 ; 47.7$ & & 6,568 & 36.9 & $35.3 ; 38.5$ & \\
\hline Total physical activity & & & & 0.7 & & & & 1.0 \\
\hline Inactive & 15,347 & 41.4 & $40.5 ; 42.4$ & & 7,827 & 58.5 & $56.8 ; 60.1$ & \\
\hline Insufficiently active & 4,922 & 13.1 & $12.4 ; 13.7$ & & 2,201 & 14.0 & $12.9 ; 15.2$ & \\
\hline Active & 17,405 & 45.5 & $44.6 ; 46.5$ & & 4,808 & 27.5 & $26.1 ; 29.0$ & \\
\hline Daily television time (hours) & & & & 0.0 & & & & 0.0 \\
\hline Up to 2 & 19,090 & 49.1 & $48.1 ; 50.1$ & & 6,947 & 44.9 & $43.1 ; 46.6$ & \\
\hline$\geq 2$ & 18,857 & 50.9 & $49.9 ; 51.9$ & & 8,035 & 55.1 & $53.4 ; 56.9$ & \\
\hline
\end{tabular}

95\% Cl: 95\% confidence interval.

* Percentage in the weighted sample;

** 95\% confidence interval in the weighted sample.

three chronic diseases was consistently more frequent in subjects with longer daily television time $(\mathrm{OR}=1.29,95 \% \mathrm{CI}: 1.09 ; 1.53, \mathrm{OR}=1.54,95 \% \mathrm{CI}: 1.25 ; 2.01$, respectively).

An interaction was observed between total physical activity level and television time in adults and older adults with NCD multimorbidity (Figures 1 and 2). Among active adults, multimorbidity frequency was higher in those spending more time watching television compared with those spending less time doing it (Figure 1). Among older adults, multimorbidity frequency was higher in inactive subjects spending less time watching television compared with those spending more time doing it, as well as in active subjects spending more time watching television when compared with those spending less time in this activity (Figure 2). Both age groups were similar regarding multimorbidity frequency between insufficiently active subjects who spend more and less time watching television.

\section{Discussion}

This study aimed to investigate the association of NCD multimorbidity with indicators of physical activity and sedentary behavior, as well as the interaction between these behaviors. Multimorbidity increased the odds of longer television time in adults and older adults. Likewise, multimorbidity reduced the odds of being active and insufficiently active, as well as the participation in commutingand work-related physical activity among adults. In older adults, multimorbidity reduced the odds of participating in domestic- and work-related physical activity.

Sedentary behavior, represented here by television time, was associated with a higher risk of NCD multimorbidity in adults and older adults from the capitals of the Brazilian states. Similar findings have been reported in studies conducted in middle-income 12 and high-income countries 21 . Watching 
Table 2

Association * of behavioral indicators with the number of chronic noncommunicable diseases in the diagnosis of multimorbidity in adults. Brazil, 2013 ( $n=37,947)$.

\begin{tabular}{|c|c|c|c|c|c|c|}
\hline \multirow[t]{2}{*}{ Variable } & \multicolumn{2}{|l|}{2 vs. 0 and 1} & \multicolumn{2}{|l|}{3 vs. 0 and 1} & \multicolumn{2}{|l|}{4 vs. 0 and 1} \\
\hline & Adjusted OR (95\%CI) & p-value & Adjusted OR (95\%CI) & p-value & Adjusted OR (95\%Cl) & p-value \\
\hline Domestic physical activity & & 0.187 & & 0.067 & & 0.321 \\
\hline No & 1.00 & & 1.00 & & 1.00 & \\
\hline Yes & $1.10(0.96 ; 1.25)$ & & $0.80(0.64 ; 1.02)$ & & $1.32(0.77 ; 2.26)$ & \\
\hline Commuting physical activity & & 0.801 & & 0.448 & & 0.379 \\
\hline No & 1.00 & & 1.00 & & 1.00 & \\
\hline Yes & $0.98(0.83 ; 1.16)$ & & $0.89(0.66 ; 1.20)$ & & $0.76(0.41 ; 1.40)$ & \\
\hline Work physical activity & & 0.461 & & $<0.001$ & & 0.008 \\
\hline No & 1.00 & & 1.00 & & 1.00 & \\
\hline Yes & $0.95(0.82 ; 1.10)$ & & $0.60(0.46 ; 0.78)$ & & $0.48(0.27 ; 0.82)$ & \\
\hline Leisure-time physical activity & & 0.001 & & 0.162 & & 0.745 \\
\hline No & 1.00 & & 1.00 & & 1.00 & \\
\hline Yes & $1.46(1.16 ; 1.84)$ & & $1.33(0.89 ; 1.98)$ & & $0.81(0.22 ; 2.94)$ & \\
\hline Total physical activity & & $<0.001$ & & 0.048 & & 0.545 \\
\hline Inactive & 1.00 & & 1.00 & & 1.00 & \\
\hline Insufficiently active & $0.66(0.48 ; 0.91)$ & & $0.79(0.47 ; 1.31)$ & & $1.15(0.33 ; 4.06)$ & \\
\hline Active & $0.54(0.41 ; 0.71)$ & & $0.66(0.43 ; 1.02)$ & & $0.79(0.25 ; 2.47)$ & \\
\hline Daily television time (hours) & & 0.007 & & $<0.001$ & & 0.022 \\
\hline Up to 2 & 1.00 & & 1.00 & & 1.00 & \\
\hline$\geq 2$ & $1.20(1.05 ; 1.38)$ & & $1.50(1.20 ; 1.88)$ & & $1.97(1.10 ; 3.52)$ & \\
\hline
\end{tabular}

95\% Cl: 95\% confidence interval; OR: odds ratio.

Note: Analysis adjusted for sex, age, marital status, ethnicity, demographic macroregion, and education level (first level), and for physical activity in the commuting, domestic, leisure-time and work domains, total physical activity and daily television time (second level).

* Values weighted for the inverse of existing telephone lines and the number of adults living in the interviewee's household.

television is one of the main activities performed by adults during leisure time 22 and deserves attention because it characterizes a risk profile that is strengthened by the combination with some behaviors affecting energy balance, such as inadequate eating and low levels of physical activity 22,23,24,25.

An inverse association was observed between NCD multimorbidity and physical activity in the work domain. Considering work-related physical activity, Mabry et al. 26 also found a reduction in the occurrence of three diseases. The work place is a social and environmental determinant of health 27 and comprises active behaviors involving occupational and commuting routine. Thus, individuals with multimorbidity who do not perform physical activities resulting from occupational demands (carrying weight or getting stand up for a long time) at work would be an important target for preventive measures.

Leisure-time physical activity, on the other hand, was associated with a risk for multimorbidity. This domain exists in the literature as a prevention 28 or without association with multimorbidity 26. The protection relationship can be attributed to leisure activity practices, which should be done with higher intensity, mainly due to the short relative duration of the equivalent training sessions 28 . A possible justification for the findings of this study is that attributing a causal relationship to the variables and raising the assumption that those with two diseases started physical activity in this domain after the conditions occured is not possible. Another justification is that the benefit of practicing physical activity outside working hours for health seems not to be enough for the deleterious effects of sedentary behavior throughout the day 11. In other words, even if activities were performed outside the occupational context, the association of long periods during work journey seems to be stronger. 
Table 3

Association * of behavioral indicators with the number of chronic noncommunicable diseases in the diagnosis of multimorbidity in older adults. Brazil, $2013(n=14,982)$.

\begin{tabular}{|c|c|c|c|c|c|c|}
\hline \multirow[t]{2}{*}{ Variable } & \multicolumn{2}{|c|}{2 vs. 0 and 1} & \multicolumn{2}{|c|}{3 vs. 0 and 1} & \multicolumn{2}{|l|}{4 vs. 0 and 1} \\
\hline & Adjusted OR $(95 \% \mathrm{CI})$ & p-value & Adjusted OR (95\%CI) & p-value & Adjusted OR (95\%CI) & p-value \\
\hline Domestic physical activity & & 0.004 & & 0.334 & & 0.025 \\
\hline No & 1.00 & & 1.00 & & 1.00 & \\
\hline Yes & $0.77(0.65 ; 0.92)$ & & $0.89(0.70 ; 1.13)$ & & $0.56(0.34 ; 0.93)$ & \\
\hline Commuting physical activity & & 0.797 & & 0.101 & & 0.427 \\
\hline No & 1.00 & & 1.00 & & 1.00 & \\
\hline Yes & $0.96(0.69 ; 1.33)$ & & $0.65(0.39 ; 1.09)$ & & $1.39(0.62 ; 3.14)$ & \\
\hline Work physical activity & & 0.548 & & 0.139 & & 0.002 \\
\hline No & 1.00 & & 1.00 & & 1.00 & \\
\hline Yes & $0.92(0.69 ; 1.22)$ & & $0.72(0.46 ; 1.11)$ & & $0.26(0.11 ; 0.62)$ & \\
\hline Leisure-time physical activity & & 0.889 & & 0.541 & & 0.359 \\
\hline No & 1.00 & & 1.00 & & 1.00 & \\
\hline Yes & $1.02(0.74 ; 1.42)$ & & $0.86(0.54 ; 1.39)$ & & $0.53(0.14 ; 2.04)$ & \\
\hline Total physical activity & & 0.129 & & 0.424 & & 0.878 \\
\hline Inactive & 1.00 & & 1.00 & & 1.00 & \\
\hline Insufficiently active & $0.72(0.39 ; 1.31)$ & & $0.91(0.47 ; 1.78)$ & & $1.03(0.23 ; 4.60)$ & \\
\hline Active & $0.67(0.39 ; 1.15)$ & & $0.77(0.42 ; 1.41)$ & & $1.11(0.18 ; 6.79)$ & \\
\hline Daily television time (hours) & & 0.004 & & $<0.001$ & & 0.068 \\
\hline Up to 2 & 1.00 & & 1.00 & & 1.00 & \\
\hline$\geq 2$ & $1.29(1.09 ; 1.53)$ & & $1.54(1.25 ; 2.01)$ & & $1.54(0.97 ; 2.45)$ & \\
\hline
\end{tabular}

95\% Cl: 95\% confidence interval; OR: odds ratio.

Note: analysis adjusted for sex, age, marital status, ethnicity, demographic macroregion, and education level (first level), and for physical activity in the commuting, domestic, leisure-time and work domains, total physical activity and daily television time (second level).

* Values weighted for the inverse of existing telephone lines and the number of adults living in the interviewee's household.

Total physical activity considering the leisure-time and commuting domains was also inversely associated with multimorbidity in adults. This finding agrees with the study by Wu et al. 29 , which indicated that combining several domains permits identifying protection against multimorbidity, considering mainly the total cumulative physical activity time. Habitual physical activity is an excellent approach to prevent multimorbidity ${ }^{30}$, in which the diversification of physical capacities ${ }^{31}$ and the constant regulation of the increase in intensity and volume have benefits 32,33 . However, light physical activities should also be encouraged because of their proven preventive effect 9 . Thus, physical activity along the day, regardless of domain, type or intensity, is inversely associated with NCD multimorbidity occurrence. Regarding the interaction between leisure-time and commuting total physical activity and sedentary behavior in adults, increasing physical activity slightly reduced the proportions of multimorbidity, which was significant in active adults who spend less time watching television compared with those spending more time doing it. Lopronzi et al. 9 also demonstrated an association of multimorbidity with sedentary behavior, regardless of physical activity. The lower prevalence of multimorbidity detected with the sufficient physical activity practice, as also reported by Bertrais et al. 34, may increase the time allocated to the activity and its intensity. Thus, physical activity seems to attenuate the occurrence of multimorbidity in relation to television time 9,34. Within this context, physical activity does not play a preventive role, but it may control a reduction in the occurrence of multimorbidity in more active subjects, regardless of television time.

In older adults, NCD multimorbidity was directly associated with increased sedentary time in front of the television. Similar results have been reported for Australian older adults 35. Harvey et al. 36 


\section{Figure 1}

Interaction * of total physical activity with sedentary behavior in the occurrence of multimorbidity in adults.

Brazil, 2013 ( $n=37,947)$.

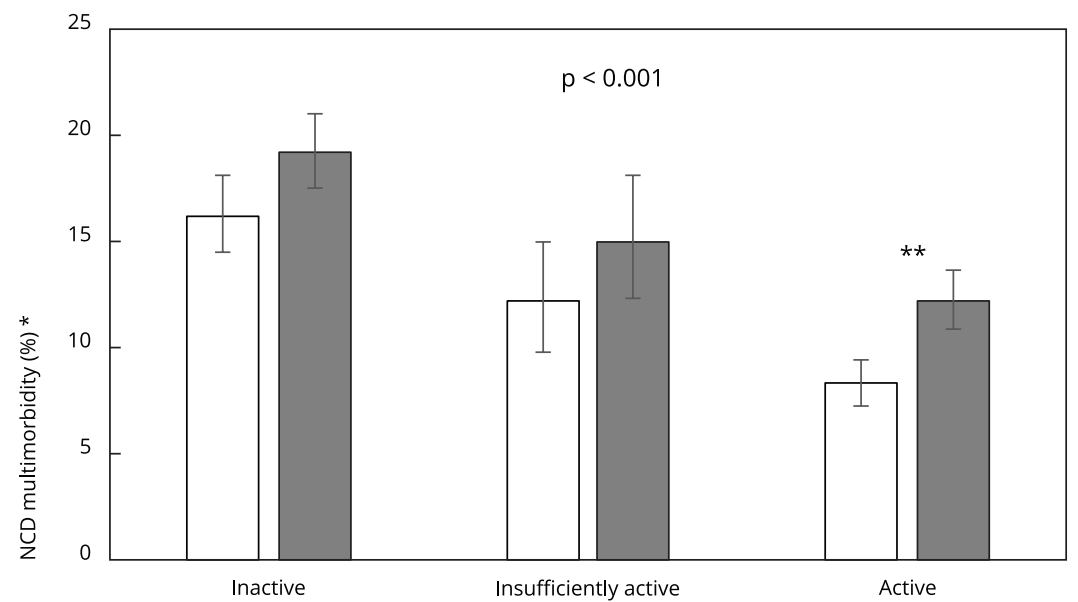

0-1 hour

$\geq 2$ hours

NCD: chronic noncommunicable diseases.

* Weighted values.

** Significance extracted from the confidence intervals.

\section{Figure 2}

Interaction * between total physical activity and sedentary behavior in the occurrence of multimorbidity in older adults. Brazil, 2013 ( $n=14,982)$.

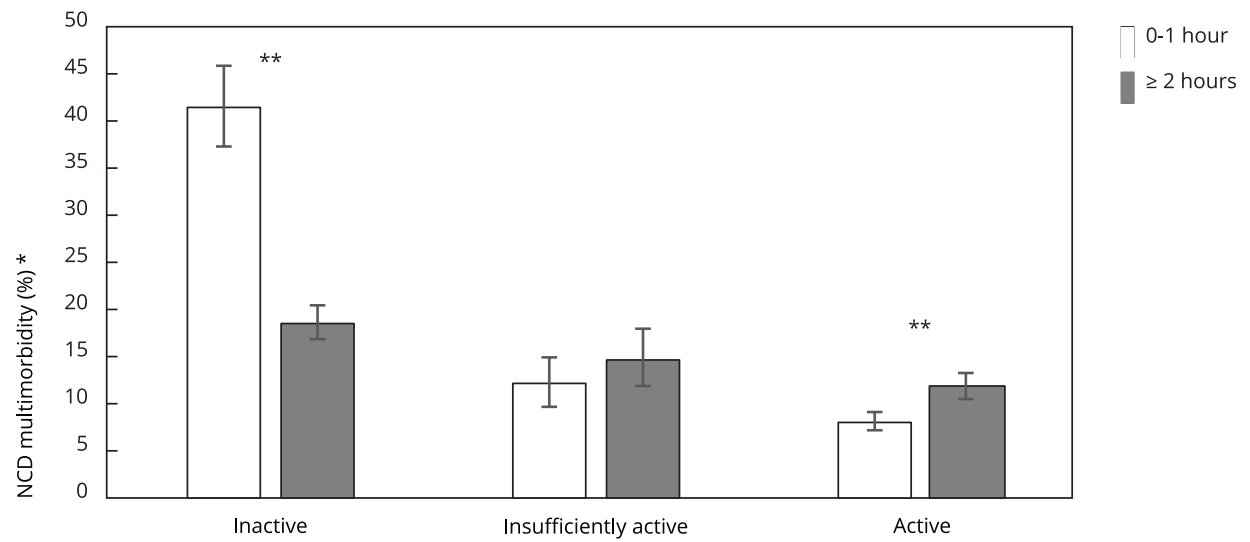

NCD: chronic noncommunicable diseases

Note: $\mathrm{p}$-value of the interaction derived from the Wald test.

* Weighted values.

** Significance extracted from the confidence intervals. 
found sitting time in front of the television is a potential predictor of poor health in older adults, attributed to lower quality of life and poor diet indicators.

The domestic and work physical activity domains were inversely associated with multimorbidity in older adults. A study has shown benefits for cardiovascular health in older adults who practice physical activity in the domestic and work domains 37 . Older adults who perform physical activities in their daily life have better functional capacity, which is considered a protective factor against multimorbidity 38 . On the other hand, the commuting or leisure-time physical activity domain was not significant for the older adults studied here. A longitudinal study investigating older adults who performed physical activity at different intensities found a lower prevalence of multimorbidity in the vigorous physical activity group 39 . Thus, the hypothesis can be raised that the intensity of physical activity rather than its duration is an important indicator of multimorbidity prevention.

Analysis of the interaction between behaviors in older adults indicates a trend towards an inversely proportional decrease in multimorbidity with increasing physical activity duration, regardless of television viewing time. Similar results have been reported by Gardiner et al. 35. The behaviors investigated in the interaction are characterized by independent organ responses 7 . However, physical activity seems to play a key role in the lower frequency of NCD multimorbidity in older adults, suggesting an effect of biological aging on this epidemiological profile 39 .

Another characteristic of the interaction between these behaviors in older adults was the higher frequency of NCD multimorbidity among inactive subjects with little television viewing time. This finding does not suggest the frequency of multimorbidity is inversely associated with less television viewing time in inactive subjects, but rather with other sedentary behaviors performed by this age group. Gardiner et al. 35 pointed the association between the risk of multimorbidity and overall sitting activities in this population. These sitting activities could result from two findings: first, subjects' functional capacity that renders them inactive 40 and, second, types of sitting activities not performed in front of a screen 41.

This was the first study to investigate the association of NCD multimorbidity with physical activity and sedentary behavior in the Brazilian scenario, which separately analyzed adults and older adults and the respective associations with behavioral indicators. Even considered a continental country, Brazil has similar Human Development Index (HDI) values in all capitals, possibly reflecting in the multimorbidity occurrence in each city, once HDI considers health information. In addition, Brazilian population is formed by different ethnicities and the results may be important to future recommendation based on evidences.

A main limitation of this study was the small number of NCDs comprising multimorbidity, which were restricted to the most prevalent diagnoses in the country, hampering the comparison with studies conducted in other countries. Self-reported diseases and body mass index (BMI), although usually applied in cross-sectional studies, need to be considered in the interpretation of the results. In it, the values of occurrence of diseases may be overestimated or underestimated and the BMI may have a potential information bias, according to the interviewee's knowledge. However, Brazil has public health programs that provide this kind of information in primary health care in all country 42 . The physical activity and sedentary behavior were also self-reported, and the physical activity may have been overestimated as well as the sedentary behavior may have been underestimated. On the other hand, physical activity questions provide different domains, offering important contributions to the analyses. Considering sociodemographic information, the retirement was not an option in the work physical activity domain, the analysis disregarded differences in results between gender, and the seasonal particularities during data collection were not included. Finally, the cross-sectional design did not allow us to exclude the possibility of reverse causality between the findings. However, considering physical activity and sedentary behavior as precedents of the conditions studied here is plausible 43 . 


\section{Conclusion}

Multimorbidity was associated with increased sedentary time and physical activity in the commuting and work domains in adults from the capitals of Brazil. In addition, it was also associated with insufficient (10 to 149 minutes) and sufficient physical activity in the leisure-time and commuting domains. Among older adults, NCD multimorbidity was associated with increased television viewing time and physical activity in the domestic and work domains. Analysis of the interaction between sedentary behavior and physical activity permitted identifying a lower frequency of multimorbidity in subjects who are active in the leisure-time and commuting domains and who spend less time watching television. A reduction in television time should be encouraged particularly in adults, with the concomitant incentive of more active behaviors without considering the volume and intensity of physical activity. We suggest measuring physical activity using objective measures in future studies to close the gaps found between the results of this study and the international literature.

\section{Contributors}

M. Christofoletti participated in the project design, data analysis and interpretation, as well as in the writing of the article, being responsible for all aspects of the study to ensure its accuracy and integrity of every part. G. F. Del Duca contributed to the project design, relevant critical review of the intellectual content, and final approval of the version to be published. D. Umpierre contributed to data interpretation, relevant critical review of the intellectual content and provided final approval of the version to be published. D. C. Malta participated in the design of the surveillance system, relevant critical review of the intellectual content, and final approval of the version to be published.

\section{Additional informations}

ORCID: Marina Christofoletti (0000-0002-56726869); Giovani Firpo Del Duca (0000-0003-08932032); Daniel Umpierre (0000-0001-6953-0163); Deborah Carvalho Malta (0000-0002-8214-5734).

\section{Acknowledgments}

The authors acknowledge the Health Surveillance Secretary of the Brazilian Ministry of Health for conducting the VIGITEL survey and providing the database.

\section{References}

1. Jakovkjević M, Ostojić L. Comorbidity and multimorbidity in medicine today: challenges and opportunities for bringing separated branches of medicine closer to each other. Psychiatr Danub 2013; 25 Suppl 1:18-28.

2. Pefoyo AJ, Bronskill SE, Gruneir A, Calzavara A, Thavorn K, Petrosyan Y, et al. The increasing burden and complexity of multimorbidity. BMC Public Health 2015; 15:415.

3. Falagas ME, Vardakas KZ, Vergidis PI. Underdiagnosis of common chronic diseases: prevalence and impact on human health. Int J Clin Pract 2007; 61:1569-79.

4. World Health Organization. Global status report on noncommunicable diseases 2010 . Geneva: World Health Organization; 2011.

5. Marengoni A, Angleman S, Melis R, Mangialasche F, Karp A, Garmen A. Aging with multimorbidity: a systematic review of the literature. Ageing Res Rev 2011; 10:430-9.

6. Boutayeb A, Boutayeb S, Boutayeb W. Multimorbidity of non communicable diseases and equity in WHO Eastern Medirerranean countries. Int J Equity Health 2013; 12:60.

7. Matthews CE, George SM, Moore SC, Bowles HR, Blair A, Park Y, et al. Amount of time spent in sedentary behaviors and cause-specific mortality in US adults. Am J Clin Nutr 2012; 95:437-45.

8. Warburton DE, Nicol CW, Bredin SS. Health benefits of physical activity: the evidence. CMAJ 2006; 174:801-9.

9. Loprinzi PD. Dose-response association of moderate-to-vigorous physical activity with cardiovascular biomarkers and all-cause mortality: considerations by individual sports, exercise and recreational physical activities. Prev Med 2015; 81:73-7.

10. Chang PC, Li TC, Wu MT, Liu CS, Li CI, Chen $\mathrm{CC}$, et al. Association between television viewing and the risk of metabolic syndrome in a community-based population. BMC Public Health 2008; 8:193. 
11. Katzmarzyk PT, Church TS, Craig CL, Bouchard C. Sitting time and mortality from all causes, cardiovascular disease, and cancer. Med Sci Sports Exerc 2009; 41:998-1005.

12. Departamento de Vigilância de Doenças e Agravos Não Transmissíveis e Promoção da Saúde, Secretaria de Vigilância em Saúde, Ministério da Saúde. VIGITEL Brasil 2012: vigilância de fatores de risco e proteção para doenças crônicas por inquérito telefônico. Brasília: Ministério da Saúde; 2013.

13. Monteiro CA, Moura EC, Jaime PC, Lucca A, Florindo AA, Figueiredo ICR, et al. Monitoramento de fatores de risco para as doenças crônicas por entrevistas telefônicas. Rev Saúde Pública 2005; 39:47-57.

14. Núcleo de Pesquisas Epidemiológicas em Nutrição, Universidade de São Paulo. SIMTEL - cinco cidades: implantação, avaliação e resultados de um sistema municipal de monitoramento de fatores de risco nutricionais para doenças crônicas não transmissíveis a partir de entrevistas telefônicas em cinco municípios brasileiros. São Paulo: Núcleo de Pesquisas Epidemiológicas em Nutrição, Universidade de São Paulo; 2007.

15. Carvalhaes MABL, Moura EC, Monteiro CA. Prevalência de fatores de risco para doenças crônicas: inquérito populacional mediante entrevistas telefônicas em Botucatu, São Paulo. Rev Bras Epidemiol 2004; 11:14-23.

16. World Health Organization. Summary: surveillance of risk factors for non communicable diseases - the WHO STEP wise approach. https://www.who.int/ncd_surveillance/media/ en/269.pdf (accessed on 23/Feb/2017).

17. Remington PL, Smith MY, Williamson DF, Anda RF, Gentry EM, Hogelin GC. Design, characteristics, and usefulness of state-based behavioral risk factor surveillance: 1981-87. Public Health Rep 1988; 103:366-75.

18. Monteiro CA, Florindo AA, Claro RM, Moura EC. Validity of indicators of physical activity and sedentariness obtained by telephone survey. Rev Saúde Pública 2008; 42:575-81.

19. Ekelund U, Steene-Johannessen J, Brown WJ, Fagerland MW, Owen N, Powellet KE, et al. Does physical activity attenuate, or even eliminate, the detrimental association of sitting time with mortality? A harmonised meta-analysis of data from more than 1 million men and women. Lancet 2016; 388:1302-10.

20. Katzmarzyk PT, Lee IM. Sedentary behaviour and life expectancy in the USA: a cause-deleted life table analysis. BMJ Open 2012; 2:e000828.

21. Ford ES, Kohl 3rd HW, Mokdad AH, Ajani UA. Sedentary behavior, physical activity, and the metabolic syndrome among U.S. adults. Obes Res 2005; 13:608-14.

22. Patel AV, Bernstein L, Deka A, Feigelson HS, Campbell PT, Gapstur SM, et al. Leisure time spent sitting in relation to total mortality in a prospective cohort of US adults. Am J Epidemiol 2010; 172:419-29.
23. Nang EE, Salim A, Wu Y, Tai ES, Lee J, Van Dam RM. Television screen time, but not computer use and reading time, is associated with cardio-metabolic biomarkers in a multiethnic Asian population: a cross-sectional study. Int J Behav Nutr Phy Act 2013; 10:70.

24. Blass EM, Anderson DR, Kirkorian HL, Pempek TA, Price I, Koleini MF. On the road to obesity: television viewing increases intake of high-density foods. Physiol Behav 2006; 88:597-604.

25. Huot I, Paradis G, Receveur O, Ledoux M. Correlates of diet quality in the Quebec population. Public Health Nutr 2004; 7:1009-16.

26. Mabry RM, Winkler EA, Reeves MM, Eakin EG, Owen N. Associations of physical activity and sitting time with the metabolic syndrome among Omani adults. Obesity 2012; 20:2290-5.

27. Alavi SS, Makarem J, Abbasi M. Metabolic syndrome: a common problem among office workers. Int J Occup Environ Med 2015; 6:34-40.

28. He D, Xi B, Xue J, Huai P, Zhang M, Li J. Association between leisure time physical activity and metabolic syndrome: a meta-analysis of prospective cohort studies. Endocrine 2014; 46:231-40.

29. Wu F, Wills K, Laslett L L, Oldenburg B, Jones G, Winzenberg T. Moderate-to-vigorous physical activity but not sedentary time is associated with musculoskeletal health outcomes in a cohort of Australian middle-aged women. J Bone Miner Res 2016; 32:708-15.

30. Loprinzi PD. Physical activity is the best buy in medicine, but perhaps for less obvious reasons. Prev Med 2015; 75:23-4.

31. Dankel SJ, Loenneke JP, Loprinzi PD. Combined associations of muscle-strengthening activities and accelerometer-assessed physical activity on multimorbidity: findings from NHANES. Am J Health Promot 2017; 31:274-7.

32. Churilla JR, Fitzhugh EC. Total physical activity volume, physical activity intensity, and metabolic syndrome: 1999-2004 National Health and Nutrition Examination Survey. Metab Syndr Relat Disord 2012; 10:70-6.

33. Hajian-Tilakia K, Heidari B, Firouzjahic A, Bagherzadehc M, Hajian-Tilakid A, Halalkhor S. Prevalence of metabolic syndrome and the association with socio-demographic characteristics and physical activity in urban population of Iranian adults: a population-based study. Diabetes Metab Syndr 2014; 8:170-6.

34. Bertrais S, Beyeme-Ondoua JP, Czernichow S, Galan P, Hercberg S, Oppert JM. Sedentary behaviors, physical activity, and metabolic syndrome in middle-aged French subjects. Obes Res 2005; 13:936-44.

35. Gardiner PA, Healy GN, Eakin EG, Clark BK, Dunstan DW, Shaw JE, et al. Associations between television viewing time and overall sitting time with the metabolic syndrome in older men and women: the Australian diabetes, obesity and lifestyle study. J Am Geriatr Soc 2011; 59:788-96. 
36. Harvey JA, Chastin SF, Skelton DA. Prevalence of sedentary behavior in older adults: a systematic review. Int J Environ Res Public Health 2013; 10:6645-61.

37. Ekblom-Bak E, Ekblom B, Vikström M, de Faire U, Hellénius M. The importance of nonexercise physical activity for cardiovascular health and longevity. Br J Sports Med 2014; 48:233-8.

38. Williams JS, Egede LE. The association between multimorbidity and quality of life, health status and functional disability. Am J Med Sci 2016; 352:45-52.

39. Dhalwani NN, O’Donovan G, Zaccardi F, Hamer M, Yates T, Davies M, et al. Long terms trends of multimorbidity and association with physical activity in older English population. Int J Behav Nutr Phys Act 2016; 13:8.
40. Wenger NK, Mattson ME, Furberg CD, Elinson J. Assessment of quality of life in clinical trials of cardiovascular therapies. Am J Cardiol 1984; 54:908-13.

41. Jannuzzi F, Cintra FA. Atividades de lazer em idosos durante a hospitalização. Rev Esc Enferm USP 2006; 40:179-87.

42. Malta DC, Santos MAS, Stopa SR, Vieira JEB, Melo EA, Reis AAC. A cobertura da Estratégia de Saúde da Família (ESF) no Brasil, segundo a Pesquisa Nacional de Saúde, 2013. Ciênc Saúde Colet 2016; 21:327-38.

43. Long GH, Johansson I, Rolandsson O, Wennberg P, Fharm E, Weinehall L, et al. Healthy behaviours and 10-year incidence of diabetes: a population cohort study. Prev Med 2015; 71:121-7. 


\section{Resumo}

Os comportamentos do estilo de vida merecem ser explorados com maior profundidade no contexto da multimorbidade de doenças crônicas não transmissíveis (DCNT). O estudo teve como objetivo investigar a associação entre multimorbidade $e$ indicadores de atividade física e comportamento sedentário em uma população brasileira representativa $(n=52.929)$. Foi realizado um inquérito transversal (VIGITEL) em 2013, nas 27 Unidades Federativas. O desfecho foi a multimorbidade, definida como a presença simultânea de $\geq 2$ DCNT, $e$ as variáveis de exposição foram atividade física (nos domínios de deslocamento para trabalho/estudo, doméstico, lazer e trabalho) e comportamento sedentário (tempo de televisão $<2$ horas/dia versus $\geq 2$ horas/dia). Foram utilizados modelos de regressão Poisson e logística multivariada (odds ratio - OR), estratificados por idade, e os respectivos intervalos de $95 \%$ de confiança, com nível de significância de 5\%. Entre 37.947 adultos, a presença de três doenças crônicas era menos frequente nos indivíduos ativos no dominio do trabalho $(\mathrm{OR}=0,60)$ e mais frequente naqueles com maior tempo de televisão por dia $(O R=1,25)$. A presença de quatro doenças era menos frequente em indivíduos ativos nos domínios de deslocamento $(O R=0,52)$ e trabalho $(O R=0,42)$. Entre 14.982 idosos, a presença de duas, três ou quatro doenças crônicas era mais frequente entre aqueles como maior tempo de televisão por dia $(O R=1,33 ; 1,55$ e 1,93, respectivamente). Finalmente, as interações entre o nível total de atividade física e tempo de televisão mostraram ser estatisticamente significativas na ocorrência da multimorbidade em ambos os grupos etários. Atividade física e comportamento sedentário estão associados com a multimorbidade e devem ser considerados fatores independentes na promoção da saúde e no tratamento dos pacientes com multimorbidade.

Doença Crônica; Exercício; Comportamento Sedentário

\section{Resumen}

Las conductas dentro del estilo de vida necesitan investigarse en el contexto de multimorbilidad de enfermedades crónicas no transmisibles (NCD). El objetivo de este estudio fue investigar la asociación de multimorbilidad con la actividad física y el comportamiento sedentario en una muestra representativa de población brasileña $(n=52.929)$. Se realizó una encuesta transversal (VIGITEL por su acrónimo en portugués) en 2013, en 27 unidades federales brasileñas. La multimorbilidad, definida como la presencia de $\geq 2 \mathrm{NCD}$, fue el resultado, $y$ la actividad física (desplazamientos, dentro del ámbito doméstico, de ocio y laboral) y comportamiento sedentario (tiempo de televisión $<2$ horas/ dia $y \geq 2$ horas/día) fueron las variables de exposición. Se usaron regresiones logísticas multinomiales (odds ratio - OR) de Poisson estratificadas por edad, así como sus respectivos intervalos de confianza 95\%, adoptando un nivel de significancia de un 5\%. Entre 37.947 adultos, la presencia de tres enfermedades crónicas fue menos frecuente en individuos activos en el ámbito laboral $(O R=0,60)$ y más frecuente entre aquellos que pasaban más tiempo frente al televisor $(O R=$ 1,25). La presencia de cuatro enfermedades fue menos frecuente en individuos activos al ir y volver del trabajo $(O R=0,52)$ y en entornos laborales $(O R=0,42)$. Entre 14.982 adultos mayores, la presencia de dos, tres y cuatro enfermedades crónicas fue consistentemente más frecuente entre aquellos con mayor tiempo de exposición a la televisión $(O R=1,33 ; 1,55$ y 1,93, respectivamente $)$. Finalmente, la interacción entre el nivel de actividad física total y la televisión que se ve diariamente fue estadisticamente significativa en la ocurrencia de la multimorbilidad en ambos grupos de edad. La actividad física y el comportamiento sedentario están asociados con la multimorbilidad y deberían estar considerados factores independientes para la promoción de la salud y para el tratamiento de pacientes con multimorbilidad.

Enfermedad Crónica; Ejercicio; Conducta Sedentaria
Submitted on $20 / \mathrm{Jan} / 2019$

Final version resubmitted on 10/May/2019

Approved on 20/May/2019 